\title{
PENGARUH MODAL INTELEKTUAL TERHADAP KINERJA KEUANGAN PERBANKAN UMUM SYARIAH BERDASARKAN ISLAMICITY PERFORMANCE INDEX
}

\author{
Mulqi Nazra*1, Suazhari $^{* 2}$ \\ ${ }^{1,2}$ Program Studi Akuntansi Fakultas Ekonomi dan Bisnis Universitas Syiah Kuala \\ e-mail: nazra.mulqi27@gmail.com ${ }^{* 1}$, suazhari@ unsyiah.ac.id ${ }^{* 2}$
}

\begin{abstract}
Abstrak
The purpose of this reaserch is to examine the influence of intellectual capital toward financial performance based on islamicity performance index of Islamic banks in Indonesia during 2015-2017. The samples of this study are twelve Islamic commercial banks that were initially selected by using purposive sampling method. Islamicity performance index is used as a measurement of financial performance of Islamic banks which are consist of profit sharing ratio and zakat performance ratio. The analysis technique performed in this study is partial least squares $(P L S)$. The results of this reaserch show that Intellectual capital has negative influence to financial performance.
\end{abstract}

Keywords: Intellectual capital, capital employed, human capital, structural capital, financial performance, and Islamicity performance index

\section{Pendahuluan}

Perkembangan perbankan syariah di Indonesia dalam beberapa tahun dinilai cukup baik, terbukti dengan meningkatnya jumlah Bank Umum Syariah (BUS) dari 6 BUS pada tahun 2009 menjadi 13 BUS pada tahun 2017. Hingga Desember 2017, terdapat 21 Unit Usaha Syariah (UUS) dan 167 Bank Pembiayaan Rakyat Syariah (BPRS). Pada periode yang sama, jumlah kantor perbankan syariah meningkat dari 1.223 kantor menjadi 2.616 kantor. Total aset BUS dan UUS mencapai Rp 424,181 triliun, meningkat 18,98\% dari tahun 2016 yang nilai asetnya masih Rp 356,504 triliun (OJK, 2018).

Hameed et al. (2004) menyatakan bahwa, berkembangnya BUS harus diimbangi dengan kinerja yang baik dalam mewujudkan kepercayaan pemangku kepentingan (stakeholders) terhadap dana yang diinvestasikan. Guna mewujudkan kepercayaan tersebut, pengukuran kinerja perbankan syariah terhadap laporan keuangannya juga harus berpedoman pada prinsip-prinsip syariah. Beberapa pakar yang ahli dalam bidang perbankan syariah di seluruh dunia telah mencoba untuk melihat kinerja perbankan syariah secara lebih komprehensif, dikarenakan perbankan syariah dan perbankan konvensional memiliki konsep operasional yang berbeda. Perbankan syariah sebagai bagian dari ekonomi Islam tidak hanya mencari keuntungan semata, namun juga memiliki tujuan ibadah, sosial, keadilan distribusi, dan lain sebagainya (Aisjah \& Hadianto, 2013).

Hameed et al. (2004) mengusulkan pengukuran kinerja keuangan BUS alternatif, yaitu Islamicity performance index, yang terdiri dari Profit Sharing Ratio (PSR) dan Zakat Performance Ratio (ZPR). Indeks pengukuran ini diyakini mampu menunjukkan kinerja keuangan BUS yang sesuai dengan prinsip-prinsip syariah (Andraeny \& Putri, 2017).

Indikator PSR dapat menunjukkan seberapa besar keberhasilan BUS dalam menyalurkan dananya ke sektor produktif. Selain itu PSR juga dapat memberikan informasi mengenai kaitannya dengan total pembiayaan serta melihat kecenderungannya, yaitu apakah tingkat bagi hasilnya meningkat, menurun, atau tetap. Berikut ditampilkan tabel sampel dari 13 bank umum syariah yang memperlihatkan kinerja keuangan diukur menggunakan profit syaring ratio. 
Tabel 1.1

Profit Sharing Ratio Bank Umum Syariah

\begin{tabular}{|c|c|c|c|c|c|}
\hline \multirow{2}{*}{ NO. } & \multirow{2}{*}{ Tahun } & \multicolumn{4}{|c|}{ Bank } \\
\cline { 2 - 5 } & & BMI & BSM & BRIS & $18,78 \%$ \\
\hline 1. & 2011 & $43,06 \%$ & $26,42 \%$ & $15,99 \%$ & $18,54 \%$ \\
\hline 2. & 2012 & $45,05 \%$ & $22,81 \%$ & $28,02 \%$ & $16,66 \%$ \\
\hline 3. & 2013 & $50,00 \%$ & $21,31 \%$ & $31,11 \%$ & $16,30 \%$ \\
\hline 4. & 2014 & $51,18 \%$ & $21,04 \%$ & $36,43 \%$ & $18,89 \%$ \\
\hline 5. & 2015 & $53,90 \%$ & $25,57 \%$ & & \\
\hline
\end{tabular}

Sumber: Mutia, (2016)

Pengukuran PSR pada BUS memperlihatkan kejadian yang berbeda-beda, ada yang mengalami peningkatan dan ada yang mengalami fluktuasi selama beberapa tahun terakhir. PSR untuk Bank Muamalat Indonesia dari tahun 2011 sampai 2015 mengalami kenaikan yang cukup stabil, dibuktikan pada tahun 2011 senilai 43,06\% menuju 53,90\% pada tahun 2015. Sedangkan untuk Bank Syariah Mandiri, Bank Rakyat Indonesia Syariah, dan Bank Negara Indonesia Syariah menunjukkan hasil yang berubah-ubah atau fluktuatif.

Indikator ZPR digunakan untuk mengukur seberapa besar pembayaran zakat yang dilakukan oleh bank (Khasanah, 2016). Indikator ini ditujukan untuk mengganti indikator konvensional, yaitu Earning Per Share (EPS). Konsep kekayaan yang dimaksud dalam indikator ZPR adalah aset bersih, bukan laba bersih seperti yang diterapkan dalam indikator konvensional. Jadi, apabila aset bersih BUS semakin tinggi, maka pembayaran zakat juga akan tinggi (Hameed et al., 2004). Berikut merupakan tampilan tabel kinerja keuangan beberapa bank umum syariah dalam hal tingkat pembayaran zakat.

Tabel 1.2

Zakat Performance Ratio Bank Umum Syariah

\begin{tabular}{|c|c|c|c|c|c|}
\hline \multirow{2}{*}{ NO. } & \multirow{2}{*}{ Tahun } & \multicolumn{4}{|c|}{ Bank } \\
\cline { 3 - 6 } & & BMI & BSM & BRIS & BNIS \\
\hline 1. & 2011 & $0,02 \%$ & $0,05 \%$ & $0,01 \%$ & $0,04 \%$ \\
\hline 2. & 2012 & $0,02 \%$ & $0,06 \%$ & $0,03 \%$ & $0,04 \%$ \\
\hline 3. & 2013 & $0,02 \%$ & $0,04 \%$ & $0,04 \%$ & $0,04 \%$ \\
\hline 4. & 2014 & $0,02 \%$ & $0,01 \%$ & $0,05 \%$ & $0,03 \%$ \\
\hline 5. & 2015 & $0,00 \%$ & $0,02 \%$ & $0,05 \%$ & $0,04 \%$ \\
\hline
\end{tabular}

Sumber: Mutia, (2016)
Zakat Performance Ratio pada bank umum syariah di atas menunjukkan hasil kinerja yang berbeda. ZPR pada BRIS mengalami kejadian peningkatan kinerja dalam hal pembayaran zakat, dibuktikan dengan rasio senilai $0,01 \%$ pada 2011 meningkat terus sampai $0,05 \%$ pada tahun 2015. ZPR untuk BMI dan BNIS cenderung stabil, dibuktikan dengan rasio untuk BMI senilai $0,02 \%$ per tahun dari 2011 sampai 2016, rasio untuk BNIS senilai 0,04\% per tahun dari 2011 sampai 2016, hanya pada tahun 2014 nilainya $0.03 \%$. sedangkan rasio untuk BSM mengalami kejadian yang fluktuatif bahkan menurun.

Sekretaris Jendral Asosiasi Bank-bank Syariah Indonesia (Asbisindo), Achmad K. Permana menjelaskan bahwa, salah satu faktor yang menyebabkan pertumbuhan kinerja keuangan BUS terhambat adalah kurangnya ketersediaan Sumber Daya Manusia (SDM) yang mumpuni dan berkompeten di bidang perbankan syariah (Kompas.com, 2012). SDM yang berkompeten di bidang perbankan syariah merupakan bagian dari human capital, dimana human capital adalah salah satu komponen dari modal intelektual yang berbicara tentang pengetahuan.

Menurut Khasanah (2016), perbankan syariah harus mengubah model operasional manajemen berbasis tenaga kerja (labor based business), menjadi model manajemen berbasis pengetahuan (knowledge based business). Tujuannya adalah untuk meningkatkan nilai tambah dan meningkatkan kinerja keuangan BUS.

Pada era ekonomi modern, yaitu ekonomi yang berdasarkan pengetahuan seperti sekarang, organisasi di seluruh dunia telah sepakat dan mengakui bahwa sumber daya tidak berwujud adalah cara bagaimana perusahaan mencapai dan mempertahankan kinerja 
yang unggul. Sumber daya tidak berwujud yang dimaksud di atas adalah modal intelektual (Al-Musali \& Ismail, 2014; Maditinos et al., 2011; Nawaz \& Haniffa, 2017; Shih et al., 2010).

Bontis et al. (2000) mendefinisikan bahwa, modal intelektual adalah pengetahuan yang dimiliki individu dan perusahaan yang akan berkontribusi terhadap keberlangsungan competitive advantages suatu perusahaan. Pengertian lain dari modal intelektual adalah kemampuan perusahaan untuk memaksimalkan sumber daya yang dimiliki oleh setiap individu manusia yang bekerja secara profesional untuk meningkatkan nilai perusahaan dan menciptakan competitive advantages (Harianto \& Syafruddin, 2013).

Modal intelektual dibagi menjadi tiga komponen, yaitu capital employed, human capital, dan structural capital. Capital employed meliputi dana yang tersedia di dalam perusahaan atau total ekuitas perusahaan. Human capital mencakup pengetahuan, keahlian, dan motivasi yang dimiliki oleh karyawan. Structural capital meliputi tekonologi informasi, budaya kerja yang baik, serta kemampuan perusahaan dalam memenuhi seluruh rutinitas perusahaan (Ulum, 2013).

Penelitian tentang modal intelektual menjadi salah satu bidang penelitian paling produktif sebagai pedoman manajemen dalam dua dekade terakhir (Nawaz \& Haniffa, 2017). Hal tersebut dibuktikan oleh berbagai penelitian yang menunjukkan adanya ketertarikan dalam meneliti sektor jasa dan lembaga keuangan khususnya lembaga keuangan Islam. Andraeny \& Putri (2017); Bustamam \& Aditia (2016); Harianto \& Syafruddin (2013); dan Ousama \& Fatima (2015) menyatakan bahwa, modal intelektual memengaruhi kinerja keuangan perbankan syariah. sementara Nurhudha \& Suwarti (2014); dan Santoso (2012) menyatakan bahwa, modal intelektual tidak memengaruhi kinerja keuangan.

Pengetahuan terhadap bidang syariah menjadi sangat penting untuk menciptakan nilai tambah dan competitive advantages bagi BUS. SDM yang bekerja di BUS kebanyakan berasal dari bank konvensional. Maka dari itu modal intelektual menarik untuk dijadikan penelitian guna mengetahui sejauh mana peran pengetahuan berpengaruh terhadap kinerja keuangan BUS.
Penelitian ini bertujuan untuk menguji pengaruh modal intelektual terhadap kinerja keuangan bank umum syariah. Hasil penelitian ini diharapkan dapat memberi manfaat bagi banyak pihak, termasuk bagi para akademisi dan penyedia layanan.

\section{Kerangka Teoritis}

\section{Resource-Based Theory}

Menurut Resource-Based Theory yang dikembangkan oleh Barney (1991), perusahaan merupakan tempat sumber daya berwujud dan tidak berwujud. Sumber daya ini akan memperoleh competitive advantage jika bernilai, langka, dan orisinal. Sumber daya yang dimaksud adalah modal intelektual (capital employed, human capital, dan structural capital).

Dalam kaitannya untuk menjelaskan bagaimana modal intelektual memengaruhi kinerja keuangan BUS, Resource-Based Theory menjelaskan bahwa kinerja keuangan BUS akan mencapai predikat baik apabila dapat menggunakan sumber daya modal intelektualnya secara efisien. Karena dengan memanfaatkan modal intelektual secara efisien, maka akan menimbulkan competitive advantage bagi BUS. Dengan begitu BUS dapat mengungguli bank-bank konvensional (Wernerfelt, 1984).

\section{Islamicity Performance Index}

Islamicity performance index merupakan indikator pengukuran kinerja keuangan suatu organisasi berdasarkan nilai-nilai materialistik dan spiritual yang terdapat dalam laporan tahunan BUS (Andraeny \& Putri, 2017; Hameed et al., 2004; Meilani et al., 2014).

\section{Profit Sharing Ratio}

Profit sharing ratio diukur dengan melihat seberapa besar pendapatan atas bagi hasil dari mudharabah dan musyarakah diterima oleh BUS terhadap pembiayaan mudharabah dan musyarakah yang dikeluarkan oleh BUS. Dengan kata lain total pendapatan bagi hasil mudharabah dan musyarakah dibagi dengan total pembiayaan mudharabah dan musyarakah. Pendapatan mudharabah dan musyarakah capat dilihat pada laporan laba rugi bagian pendapatan, sedangkan pembiayaan mudharabah dan musyarakah dapat dilihat pada laporan posisi keuangan bagian neraca. 
PSR dipilih sebagai ukuran untuk kinerja keuangan karena transaksi bagi hasil dianggap sebagai tujuan utama BUS. Penting untuk mengukur kinerja keuangan BUS melalui skema bagi hasil karena dapat menunjukkan seberapa besar keberhasilan yang diperoleh ketika menyalurkan dananya ke sektor produktif. Pengukuran terhadap bagi hasil ini juga dapat memberikan informasi mengenai kaitannya dengan total pembiayaan serta melihat kecenderungannya, yaitu apakah meningkat, menurun, atau tetap tidak berubah (Hameed et al., 2004).

\section{Zakar Performance Ratio}

ZPR diukur dengan melihat seberapa besar zakat perusahaan yang dibayarkan oleh BUS terhadap aset bersih atau kekayaan bersih yang dimiliki BUS. Dengan kata lain ZPR diukur dengan total zakat yang dibayarkan BUS pada tahun berjalan dibagi dengan aset bersih BUS tahun berjalan. Total pembayaran zakat perusahaan dapat dilihat pada laporan arus kas perusahaan, sedangkan nilai aset bersih dapat dilihat pada laporan posisi keuangan dengan mengurangi nilai total aset dengan total kewajiban.

ZPR dipilih untuk mengukur kinerja keuangan BUS karena zakat merupakan salah satu perintah wajib dalam Islam. Baydoun \& Willett (2000) dan Hameed et al. (2004) menyatakan bahwa, dikarenakan zakat merupakan salah satu perintah wajib dalam Islam, jadi zakat harus menjadi salah satu tujuan akuntansi syariah. $Z P R$ itu sendiri dimaksudkan untuk mengganti indikator konvensional yaitu, Earning Per Share (EPS). Kekayaan dalam metode ini adalah yang didasarkan pada aset bersih, bukan laba bersih seperti yang diterapkan dalam metode konvensional. Maka dari itu, apabila aset bersih bank lebih tinggi, pembayaran zakat juga akan tinggi.

\section{Modal Intelektual}

Modal intelektual adalah kemampuan perusahaan untuk memaksimalkan sumber daya yang dimiliki oleh karyawan dan manajer yang bekerja secara profesional untuk meningkatkan nilai perusahaan agar terciptanya competitive advantages dan memiliki daya saing yang tinggi (Harianto \& Syafruddin, 2013).

Pada penelitian ini, konsep modal intelektual yang digunakan berasal dari Pulic (1998), yang dimodifikasi oleh Ulum (2013), yaitu capital employed, human capital, dan structural capital. Indikator pengukurannya menggunakan Islamic Banking-Value Added Intellectual Coefficient (iBVAIC).

Pada tahun 1997, untuk pertama kalinya Pulic merumuskan metode pengukuran modal intelektual yaitu Value Added Intellectual Coefficient (VAIC ${ }^{\mathrm{TM}}$ ). Namun pada tahun 2013, Ulum memodifikasi metode tersebut agar dapat digunakan terhadap organisasi berbasis syariah, metode tersebut dinamakan iBVAIC. Tujuannya untuk menyajikan informasi tentang value creation efficiency dari pemanfaatan aset berwujud dan aset tidak berwujud perusahaan. Indikator ini dikonstruksi dari akun-akun dalam laporan tahunan, seperti neraca dan laba rugi. Perbedaan indikator iB-VAIC yang modifikasi oleh Ulum (2013) terhadap indikator VAICTM yang dirumuskan oleh Pulic (1998) tidak banyak yang berbeda, hanya saja terletak pada akun-akun yang menghitung Value Added (VA).

Perhitungan dalam metode iB-VAIC diawali dengan melihat sejauh mana kemampuan perusahaan dalam menciptakan Value Added (VA). VA adalah indikator yang dapat menunjukkan kemampuan perusahaan dan menilai keberhasilan bisnis perusahaan dalam penciptaan nilai (value creation). Output dikurang input adalah cara untuk menghitung VA (Ulum, 2013).

Output (OUT) meliputi seluruh pendapatan operasional dan nonoperasional perusahaan. Sedangkan input (IN) meliputi semua beban yang dipakai guna memperoleh pendapatan, kecuali beban karyawan, karena berperan aktif terhadap proses value creation. Kemudian VA dipengaruhi oleh capital employed, human capital, dan structural capital. (Ulum, 2013).

\section{Capital Employed}

Capital employed adalah dana yang teesedia di dalam perusahaan atau total ekuitas perusahaan (Ulum, 2013). Hubungan VA dengan capital employed dinamakan Value Added Capital Employed (VACA). VACA merupakan indikator dari capital employed atas terciptanya VA (Ulum, 2013). Asumsi dari capital employed adalah "jika satu unit dari capital employed menghasilkan return yang lebih besar dari pada perusahaan lain, maka perusahaan tersebut lebih baik dalam memanfaatkan capital employed-nya" (Pulic, 
2000). Capital employed yang dimanfaatkan lebih baik adalah bagian dari modal intelektual.

\section{Human Capital}

Human capital adalah kemampuan atau keahlian yang dimiliki oleh seseorang untuk dijadikan ukuran dalam menentukan pemberian imbalan (Ardiyos, 2008:489). Hubungan VA dengan human capital dinamakan Value Added Human Capital (VAHU). VAHU menunjukkan besaran biaya yang dikeluarkan untuk pekerja dari VA yang dihasilkan. indikator dari human capital adalah beban atau gaji karyawan (Ulum, 2013).

\section{Structural capital}

Structural capital adalah pengetahuan yang dimiliki oleh perusahaan. Pengetahuan tersebut meliputi kebiasaan, budaya, proses produksi, sistem informasi, teknologi informasi, database, hubungan dan kesetiaan pelanggan, hubungan pemasok, merk dagang, dan reputasi perusahaan (Zéghal \& Maaloul, 2010).

Hubungan VA dengan structural capital dinamakan Structural Capital Value Added (STVA). STVA menunjukkan seberapa besar pengaruh structural capital terhadap penciptaan nilai. STVA mengukur jumlah structural capital yang dibutuhkan untuk menghasilkan 1 (satu) rupiah dari VA. Structural capital bukanlah ukuran yang bebas sebagaimana human capital, structural capital terikat terhadap value creation. Semakin besar kontribusi human capital dalam value creation, maka akan semakin kecil kontribusi structural capital dalam hal tersebut. Cara menghitung structural capital adalah dengan mengurangi human capital terhadap VA (Ulum, 2013).

Pengaruh modal intelektual terhadap kinerja keuangan bank umum syariah dapat dilihat pada gambar 2.1.

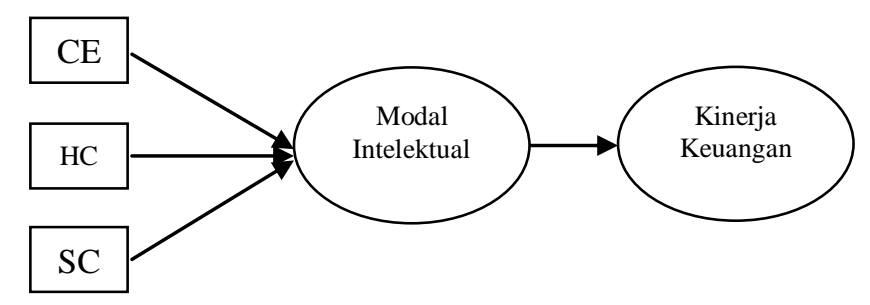

Gambar 2.1 Kerangka Pemikiran

\section{Hipotesis}

Berdasarkan landasan teori dan kerangka pemikiran yang telah dipaparkan diatas, maka dapat dinyatakan hipotesis penelitian sebagai berikut:

$\mathrm{H}_{1}$ : Modal intelektual berpengaruh terhadap kinerja keuangan

\section{Metode Penelitian}

\section{Populasi dan Sampel}

Populasi merupakan subjek atau objek yang menurut peneliti mempunyai kualitas dan karakteristik untuk diteliti dan kemudian ditarik kesimpulannya (Sugiyono, 2010:61). Populasi dalam penelitian ini adalah BUS yang terdaftar di OJK pada tahun 2015, 2016, dan 2017.

Sampel merupakan bagian dari populasi yang akan diteliti. Sampel akan mewakili hasil dari penelitian terhadap populasi tersebut. Pengambilan sampel dilakukan dengan metode purposive sampling. Purposive sampling adalah metode penarikan sampel dengan menetapkan kriteria tertentu (Kuntjojo, 2009:35).

Adapun kriteria sampel yang digunakan dalam penelitian ini adalah:

1) BUS yang terdaftar di OJK selama periode tahun 2015-2017, baik yang terbuka maupun yang tertutup.

2) BUS yang mempublikasikan laporan tahunan secara lengkap selama periode tahun 2015-2017 dan sesuai PSAK 101 tentang penyajian laporan keuangan syariah.

\section{Tabel 3.1}

\section{Penentuan Sampel Penelitian}

\begin{tabular}{|l|l|l|}
\hline No. & Kriteria Sampel & Jumlah \\
\hline 1. & $\begin{array}{l}\text { Bank umum syariah yang terdaftar di } \\
\text { OJK selama periode 2015-2017 }\end{array}$ & 13 \\
\hline 2. & $\begin{array}{l}\text { Bank umum syariah yang tidak } \\
\text { mempublikasikan laporan tahunan } \\
\text { selama periode 2015-2017 }\end{array}$ & $(1)$ \\
\hline Jumlah sampel per tahun & $\mathbf{1 2}$ \\
\hline Jumlah observasi (12x3) & $\mathbf{3 6}$ \\
\hline
\end{tabular}

Sumber: Data diolah, (2018)

\section{Sumber Dan Teknik Pengumpulan Data}

Data sekunder merupakan sumber data yang digunakan di dalam penelitian ini. Data sekunder adalah sumber data informasi yang sudah ada (Sekaran 
\& Bougie, 2017:130). Data sekunder pada penelitian ini meliputi laporan tahunan yang diterbitkan oleh BUS dan juga bahan-bahan kepustakaan yang berkaitan denga penelitian ini sehingga dapat digunakan sebagai referensi, seperti buku-buku dan jurnal.

Dokumentasi merupakan teknik yang digunakan untuk pengumpulan data. Caranya adalah dengan mempelajari dokumen atau catatan-catatan perusahaan, studi pustaka dari berbagai literatur, dan sumber lain yang berkaitan dengan variabel penelitian.

\section{Operasional Variabel}

\section{Variabel Terikat}

Variabel kinerja keuangan diukur dengan menggunakan dua indikator dari Islamicity performance index yang dikembangkan oleh Hameed et al. (2004).

$$
\begin{aligned}
& \mathrm{PSR}=\frac{\text { Mudharabah }+ \text { Musyarakah }}{\text { Total Financing }} \\
& \mathrm{ZPR}=\frac{\text { Zakat }}{\text { Net } \text { asset }}
\end{aligned}
$$

\section{Variabel Bebas}

Variabel Modal intelektual diukur menggunakan metode yang dirumuskan oleh Ulum (2013). Metode pengukurannya bernama Islamic Bank-Value Added Intellectual Coefficient (iB-VAIC) yang dikontruksi dari akun-akun di dalam laporan tahunan BUS. Langkah pertama pada metode ini ialah dengan menghitung seberapa besar kemampuan perusahaan untuk menciptakan nilai tambah atau Islamic BankValue Added (iB-VA).

Tahap pertama, menghitung iB-VA dengan menggunakan formula sebagai berikut:

$$
\mathrm{iB}-\mathrm{VA}=\mathrm{OUT}-\mathrm{IN}
$$

\section{keterangan:}

OUT (ouput) :pendapatan yang diperoleh dari pendapatan operasi utama kegiatan syariah, ditambah pendapatan operasi lainnya, dan dikurangi hak pihak ketiga atas bagi hasil dana syirkah temporer

IN (input) : beban yang diperoleh dari beban operasional, ditambah beban nonoperasional, dan dikurangi beban karyawan.
Setelah menghitung iB-VA, selanjutnya adalah menghitung rasio Islamic Bank-Value Added Capital Employed (iB-VACA). Rasio iB-VACA menunjukkan seberapa besar kontribusi dari setiap capital employed terhadap value added perusahaan (Ulum, 2013).

Keterangan:

$$
\mathrm{iB}-\mathrm{VACA}=\frac{V A}{C E}
$$

$$
\begin{array}{ll}
\mathrm{VA} & \text { : Value added } \\
\mathrm{CE} & \text { : capital employed (ekuitas) }
\end{array}
$$

Langkah selanjutnya untuk mengukur human capital ialah dengan menggunakan rasio Islamic BankValue Added Human Capital (iB-VAHU). Rasio ini menunjukkan seberapa besar kontribusi human capital yang telah diinvestasikan terhadap value added BUS (Ulum, 2013).

$$
\mathrm{iB}-\mathrm{VAHU}=\frac{V A}{H C}
$$

Keterangan:

$\begin{array}{ll}\text { VA } & \text { : Value added } \\ \text { HC } & \text { : Human capital (beban karyawan) }\end{array}$

Langkah selanjutnya mengukur structural capital menggunakan rasio Islamic Bank-Value Added Structural Capital (iB-STVA). Rasio ini merupakan indikasi bagaimana keberhasilan structural capital dalam menciptakan value added BUS (Ulum, 2013).

$$
\mathrm{iB}-\mathrm{STVA}=\frac{S C}{V A}
$$

Keterangan:

SC : Structural capital (iB-VA - HC)

VA : Value added

Langkah terakhir mengukur rasio komponen modal intelektual secara keseluruhan (Ulum, 2013).

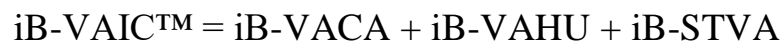

Keterangan:

iB-VACA : rasio capital employed

iB-VAHU : rasio human capital

iB-STVA : rasio structural capital 


\section{Metode Analisis}

Pengujian

hipotesis

dalam penelitian dilakukan dengan pendekatan Structural Equation Model (SEM) berbasis Partial Least Square (PLS) menggunakan software WarpPLS 4.0. Metode PLS-SEM dipilih pada penelitian ini berdasarkan pertimbangan bahwa, terdapat dua variabel laten (modal intelektual dan kinerja keuangan) yang diukur dengan menggunakan lebih dari satu indikator dan dibentuk dengan model indikator formatif. Model indikator formatif adalah indikator yang memengaruhi konstruk, maksudnya arah hubungan kausalitas dari indikator menuju ke konstruk (Ghozali \& Latan, 2014:15).

\section{Uji outer Model}

Outer model dilakukan untuk menilai reliabilitas dan validitas dari indikator-indikator pembentuk konstruk laten.

1) Indicator Reliability

Indicator reliability yaitu besarnya variance dari indikator/item untuk menerangkan serta menjelaskan konstruk laten, rule of thumb yang biasanya digunakan untuk menilai signifikansi weight di indicator reliabilty yaitu P-value $<0,05$ (level $=5 \%$ ) (Ghozali \& Latan, 2014:96).

2) Collinearity

Karena konstruk formatif merupakan hubungan regresi berganda dari indikator ke konstruk, maka isu collinearity menjadi sangat penting untuk diperhatikan. Rule of thumb yang biasanya digunakan untuk menilai collinearity konstruk yaitu, Variance Inflation Factor (VIF). Nilai cut off yang dapat diterima untuk VIF adalah $<2,5$ (Ghozali \& Latan, 2014:97).

\section{Uji Inner Model}

Inner model bertujuan untuk memprediksi hubungan antar variabel laten dengan melihat seberapa besar variance yang dapat dijelaskan dan untuk mengetahui signifikansi dari $P$-value.

1) Cofficients of determination $\left(R^{2}\right)$ atau Adjusted $R^{2}$

Nilai $R^{2}$ atau adjusted $R^{2}$ digunakan untuk mengukur tingkat variasi perubahan variabel independen terhadap variabel dependen. Semakin besar nilai $R^{2}$ atau adjusted $R^{2}$ maka prediktor model semakin baik dalam menjelaskan variance
(Ghozali \& Latan, 2014:98). Nilai $R^{2}$ terdiri atas $\leq 0,70$ (kuat), $\leq 0,45$ (moderate) dan $\leq 0,25$ (lemah) (Ghozali \& Latan, 2014:106).

2) Predictive Relevance $\left(Q^{2}\right)$

Predictive Relevance $\left(Q^{2}\right)$ sangat penting untuk menilai validitas prediktif dari model yang kompleks (Akter et al., 2011; Geisser, 1975; Stone, 1974). Validitas prediktif ini untuk variabel laten eksogen dikatakan baik jika nilai $Q^{2}$ lebih besar dari 0 dan jika $Q^{2}<0$ maka menunjukkan bahwa model kurang memiliki predictive relevance (Ghozali \& Latan, 2014:106).

3) APC (Average Adjusted R-Squared), ARS (Average $R$-Squared) dan AARS (Average Adjusted R-Squared)

The rule of thumb untuk APC, ARS dan AARS adalah $p$-value. $P$-value $\leq 0,05$ (Ghozali \& Latan, 2014:106).

4) AVIF (Average Block Variance Inflation Factor) dan AFVIF (Average Full Collinearity VIF)

AVIF dan AFVIF memiliki rule of thumb sebesar $\leq 3,3$, namun nilai $\leq 5$ masih dapat diterima (Ghozali \& Latan, 2014:106).

5) Signifikansi $P$-value

Signifikansi P-value diukur untuk mengetahui pengaruh antar variabel berdasarkan hipotesis yang dibangun berdasarkan prosedur resampling. Nilai signifikansi yang digunakan yaitu dengan nilai P-value 0,05 (significance level $=5 \%$ ).

\section{Hasil dan Pembahasan \\ Deskripsi Objek Penelitian}

Penelitian ini bertujuan untuk menguji pengaruh modal intelektual terhadap kinerja keuangan bank umum syariah (BUS) berdasarkan Islamicity performance index yang terdaftar di OJK tahun 20152017. Objek Purposive sampling digunakan sebagai metode pemilihan objek dalam peneltian ini, karena terdapat beberapa kriteria yang disyaratkan, yaitu pertama, BUS yang terdaftar di OJK selama periode tahun 2015-2017 baik yang tertutup maupun yang terbuka. Kedua, BUS yang mempublikasikan laporan tahunan selama periode tahun 2015-2017 dan sesuai PSAK 101 tentang penyajian laporan keuangan syariah.

Data panel (pooled data) digunakan sebagai horizon waktu, karena memerlukan lebih dari satu 
tahap pengumpulan data pada waktu yang berbeda. Berdasarkan data yang diperoleh dari situs daring masing-masing BUS dengan kriteria yang telah ditetapkan, diperoleh sampel sebanyak 12 BUS untuk satu tahun, sehingga untuk periode tiga tahun jumlah sampel penlitian menjadi 36 data observasi.

Structural Equation Model (SEM) berbasis Partial Least Square (PLS) atau WarpPLS 4.0 digunakan untuk menganalisis data. Evaluasi model dalam PLS-SEM akan melewati dua tahapan. Pertama, indikator-indikator pembentuk konstruk laten (outer model) dinilai reliabilitas dan validitasnya. Kedua, melihat seberapa besar variance yang dapat dijelaskan dan untuk mengetahui signifikansi dari P-value (inner model) dengan memprediksi hubungan antar variabel laten.

\section{Hasil Analisis Data Penelitian \\ Uji Outer Model}

Penelitian ini menggunakan data sekunder dan setiap variabel laten menggunakan indikator formatif. Untuk menguji data, maka hal pertama yang dilakukan adalah mengevaluasi model pengukuran (outer model) dan selanjutnya mengevaluasi model struktural (inner model). Oleh karena penelitian ini menggunakan mode pengukuran formatif, maka rule of thumb yang harus terpenuhi adalah (1) bobot indikator (indicator weight) harus signifikan secara statistik yaitu nilai $\mathrm{p}$ kurang dari 0,05 , (2) multikolinearitas (VIF) lebih kecil dari 2,5 (Ghozali \& Latan, 2014:97). Berdasarkan rule of thumb, evaluasi hasil pengukuran adalah sebagai berikut.

Tabel 4.1

Indicator Weight

\begin{tabular}{lllll}
\hline & P-value & & VIF & \\
\hline PSR & $<0,001$ & sig. & 1,016 & sig. \\
ZPR & $<0,001$ & sig. & 1,016 & sig. \\
VACA & $<0,001$ & sig. & 1,770 & sig. \\
VAHU & $<0,001$ & sig. & 1,779 & sig. \\
STVA & $<0,001$ & sig. & 1,016 & sig. \\
\hline
\end{tabular}

Sumber: WarpPLS 4.0, (2018)

Dari hasil output indicator weights pada tabel $4.1 \mathrm{di}$ atas dapat dilihat bahwa indikator pembentuk variabel kinerja keuangan (KK) yaitu, PSR dan ZPR menghasilkan indicator weight $<0,001$ yang berarti bahwa kedua indikator tersebut dinyatakan signifikan. Indikator pembentuk variabel modal intelektual yaitu,
VACA, VAHU, dan STVA juga menghasilkan indicator weight $<0,001$ yang berarti ketiga indikator tersebut dinyatakan signifikan. Nilai Variance Inflation Factor (VIF) per indikator pada tabel di atas menunjukkan hasil $<2,5$ yang berarti tidak terjadi problem collinearity antar indicator.

\section{Uji Inner Model}

Setelah tahap pertama selesai dievaluasi, maka dilanjutkan ke tahap kedua, yaitu mengevaluasi model struktural (inner model). Hasil pengujian model struktural (inner model) menghasilkan output 'model fit and quality indices' yaitu APC, ARS, AARS, AVIF dan AFVIF. Model fit APC menghasilkan nilai yang signifikan, yaitu $\mathrm{P}<0,05$. ARS menunjukkan nilai $\mathrm{P}=$ 0,095 yang berarti tidak signifikan, karena penelitian ini menggunakan nilai moderate $\mathrm{P}<0,05$, namun di dalam buku Ghozali \& Latan (2014:96), nilai $\mathrm{P}=$ 0,095 masih dapat diterima karena $\mathrm{P}<0,10$. Sedangkan AARS menunjukkan nilai yang tidak signifikan, yaitu $P>0,05$. Begitu juga dengan AFVIF yang menghasilkan nilai 1,093 yaitu di bawah nilai 3,3 yang berarti sesuai dengan rule of thumb-nya (lihat tabel 4.2). Mengacu pada ketentuan tersebut, dapat disimpulkan bahwa model penelitian ini fit. Pada tabel 4.2 menunjukkan koefisien dan nilai $\mathrm{p}$ dari hubungan IC ke kinerja keuangan. Hubungan IC menunjukkan nilai koefisien negatif $-0,292$ signifikan pada $\alpha 0,010$.

\section{Tabel 4.2}

\section{Model Fit and Quality Indices, Path Coefficients and} $P$-values

\begin{tabular}{|c|c|c|c|c|}
\hline $\begin{array}{l}\text { Model Fit and } \\
\text { Quality Indices }\end{array}$ & $\begin{array}{l}\text { APC } \\
0,292 \\
\text { ARS } \\
0,085 \\
\text { AARS } \\
0,059 \\
\text { AFVIF } \\
=1,093\end{array}$ & $\begin{array}{l}= \\
=\end{array}$ & $\begin{array}{l}\mathrm{P}=0,001 \\
\mathrm{P}=0,095 \\
\mathrm{P}=0,137 \\
\text { Ideally }<= \\
3,3\end{array}$ & \\
\hline $\begin{array}{l}\text { Path Coefficients } \\
\text { and P-values }\end{array}$ & IC & & $-0,292$ & $\mathrm{P}<0,010$ \\
\hline
\end{tabular}

Sumber: WarpPLS 4.0, (2018)

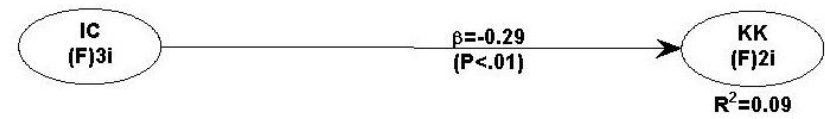

Gambar 4.1 Output WarpPLS 4.0 
Tabel 4.3 menyajikan data $R$-Squared, Adjusted $R$-Squared, $Q$-Squared dan Full Collinearity VIF. $R$ Squared menunjukkan berapa persentase variansi variabel dependen dapatdijelaskan oleh variabel independen. Nilai $R^{2}$ yang dihasilkan adalah $8,5 \%$. $Q$ Squared merupakan validitas prediktif atau relevansi dari sekumpulan variabel laten prediktor pada variabel kriterion (Ghozali \& Latan, 2014:100). Hasil estimasi menunjukkan validitas prediktif yang baik yaitu $Q^{2}$ sebesar 0,153 lebih besar dari nol. Full Collinearity VIF merupakan hasil pengujian kolinearitas penuh yang meliputi multikolinearitas vertikal dan lateral (Ghozali \& Latan, 2014:102). Hasil menunjukkan nilai Full Collinearity VIF kurang dari 3,3 sehingga model bebas dari masalah kolinearitas.

Tabel 4.3

R-Squared, Adjusted R-Squared, Q-Squared, \& Full Collinearity VIF

\begin{tabular}{lll}
\hline & KK & IC \\
\hline R-squared & 0,085 & \\
Adj. $R$-squared & 0,059 & \\
Full Collinearity VIF & 1,093 & 1,093 \\
$Q$-squared & 0,153 & \\
\hline
\end{tabular}

Sumber: WarpPLS 4.0, (2018)

\section{Pengujian Hipotesis}

\section{Pengaruh Modal intelektual Terhadap Kinerja} Keuangan

Berdasarkan hasil uji inner model, modal intelektual mempunyai path coefficients sebesar -0,292 dan $p$-value sebesar 0,002 yang berarti lebih kecil dari 0,05 yang menjadi level signifikansi antar variabel. Hasil pengujian tersebut menunjukkan bahwa modal intelektual berpengaruh negatif terhadap kinerja keuangan bank umum syariah selama periode tahun 2015-2017. Sehingga dapat disimpulkan bahwa hasil ini mendukung hipotesis ke empat $\left(H_{1}\right)$.

Teori sumber daya (resource-based theory) yang dinyatakan oleh Wernerfelt (1984), BUS akan memperoleh kinerja keuangan yang baik, apabila perusahaan dapat memanfaatkan sumber daya modal intelektualnya secara efisien. Akibat memanfaatkan modal intelektual secara efisien, maka akan menimbulkan competitive advantage bagi BUS.

Menurut penelitian ini, modal intelektual berpengaruh negatif terhadap kinerja perusahaan. Semakin banyak modal intelektual yang diinvestasikan, maka akan berdampak pada semakin menurunnya kinerja perusahaan yang diperoleh. Hal ini menjelaskan bahwa banyaknya investasi terhadap modal intelektual tidak selalu dapat meningkatkan kinerja perusahaan, melainkan dapat membuat kinerja perusahaan menurun karena pemanfaatan dan pengelolaannya yang tidak maksimal (Riyandini et al., 2016). Hal ini juga diperkuat dengan hasil tabulasi rasio setiap komponen modal intelektual yang menunjukkan bahwa, beberapa BUS rasio modal intelektualnya mendapatkan hasil yang minus (lihat Lampiran 1).

Murthy \& Mouritsen (2011) menyatakan bahwa, mungkin ada trade-off antara komponen modal intelektual dan ada bentuk modal intelektual yang tidak produktif. Perusahaan menganggap tidak semua investasi dalam komponen modal intelektual menguntungkan (Youndt et al., 2004). Akibatnya peran modal intelektual itu sendiri tidak mkasimal dalam meningkatkan kinerja keuangan perusahaan. Hasil dari rasio setiap komponen pada tabulasi data pada lampiran 1 menunjukkan bahwa, rasio untuk human capital lebih tinggi dari kedua komponen lainnya. Artinya BUS lebih terfokus pada human capital. Hasil penelitian ini didukung oleh penelitian Riyandini et al. (2016) yang menyatakan bahwa, modal intelektual berpengaruh negatif terhadap kinerja keuangan.

\section{Kesimpulan, Keterbatasan dan Saran}

Berdasarkan hasil analisis data dan pembahasan yang telah disajikan pada bab sebelumnya, maka dapat ditarik kesimpulan untuk penelitian ini. Di samping itu juga akan dikemukakan keterbatasan dan saran berhubungan dengan penelitian ini, yaitu sebagai berikut:

\section{Kesimpulan}

Modal intelektual mempengaruhi kinerja keuangan BUS berdasarkan Islamicity performance index selama periode 2015-2017 secara negatif.

\section{Keterbatasan}

1) Penelitian ini hanya meninjau kinerja keuangan BUS dari kajian modal intelektual, sementara masih banyak variabel lain yang dapat ditinjau untuk melihat faktor apa saja yang dapat mempengaruhi kinerja keuangan BUS.

2) Penelitian ini hanya menggunakan sampel selama 3 tahun, yaitu 36 data observasi dari 12 sampel 
bank umum syariah. Penggunaan 36 data observasi ini dikarenakan peneliti menganggap PLS mampu menyelesaikan pengujian regresi dengan ukuran sampel yang kecil.

\section{Saran}

1) Penelitian selanjutnya sebaiknya menggunakan sampel lebih dari 3 tahun agar lebih banyak perbankan yang tercakup ke dalam penelitian dan agar hasil penelitian yang tercakup juga lebih luas.

2) Pengukuran modal intelektual terhadap kinerja lembaga keuangan syariah tidak hanya terbatas pada perbankan, namun juga dapat dilakukan pada asuransi syariah, Lembaga Amil Zakat (LAZ), Baitul Mal Wattamwil (BMT).

3) Mengukur kinerja keuangan tidak hanya berdasarkan aspek keuangan seperti Islamicity performance index, namun juga dapat diukur dari aspek lainnya seperti Islamicity disclosure index, yang terdiri dari shariah compliance, corporate governance index, dan social/environment index.

\section{Daftar Pustaka}

Aisjah, S., \& Hadianto, A. E. (2013). Performance Based Islamic Performance Index (Study on the Bank Muamalat Indonesia and Bank Syariah Mandiri). Asia-Pasific Management and Business Application, 2(2), 98-110.

Al-Musali, M. A. K., \& Ismail, K. N. I. K. (2014). Intellectual Capital and its Effect on Financial Performance of Banks: Evidence from Saudi Arabia. Procedia - Social and Behavioral Sciences, 164, 201-207. https: //doi.org /10.1016/j.sbspro.2014.11.068

Andraeny, D., \& Putri, D. D. (2017). Islamicity Financial Performance Index in Indonesian Islamic Banks. Shirkah Journal of Economics and Business, 2(3), 2503-4243.

Ardiyos, S. (2008). Kamus Besar Akuntansi. Jakarta: Citra Harta Prima.

Barney, J. B. (1991). Firm Resources and Sustained Competitive Advantage. Journal of Management. https://doi.org /10.1177/01492 0639101700108

Baydoun, N., \& Willett, R. (2000). Islamic Corporate Reports. Abacus, 36(1), 71-90. https://doi.org/10.1111/1467-6281.00054
Bontis, N., Keow, W. C. C., \& Richardson, S. (2000). IC in Malaysian Industries Intellectual Capital and Business Performance in Malaysian Industries. Journal of Intellectual Capital, 1(1), 85-100. https: //doi.org /10 .1108 $/ 14691930010324188$

Bustamam, \& Aditia, D. (2016). Pengaruh Intellectual Capital, Biaya Intermediasi, dan Islamicity Performance Index terhadap Profitabilitas Syariah di Indonesia. Jurnal Dinamika Akuntansi Dan Bisnis, 3(1), 17-25.

Ghozali, I., \& Latan, H. (2014). Partial Least Squares Konsep, Metode, dan Aplikasi Menggunakan Program WarpPLS 4.0 (Edition 2). Semarang: Universitas Diponegoro.

Hameed, S., Wirman, A., Alrazi, B., Nazli, M., \& Pramono, S. (2004). Alternative Disclosure and Performance Measures for Islamic Banks. In Second Conference on Administrative Sciences: Meeting the Challenges of the Globalization Age, King Fahd University of Petroleum \& Minerals, Dhahran, Saudi Arabia (pp. 19-21). https://doi.org $/ 10.1017$ /CBO9781107415324.004

Harianto, N., \& Syafruddin, M. (2013). Pengaruh Modal Intelektual terhadap Kinerja Bisnis Bank Umum Syariah (BUS) di Indonesia. Diponegoro Journal of Accounting, 2(4), 1-10.

Khasanah, A. N. (2016). Pengaruh Intelektual Capital dan Islamicity Performance Index terhadap Kinerja Keuangan Perbankan Syariah di Indonesia. Jurnal Nominal, 5(1), 1-18.

Kompas.com. (2012). Tiga Masalah Terbesar di Bank Syariah. Retrieved April 9, 2018, from www.kompas.com

Kuntjojo. (2009). Metodologi Penelitian. Kediri: Universitas Nusantara PGRI Kediri.

Maditinos, D., Chatzoudes, D., Tsairidis, C., \& Theriou, G. (2011). The Impact of Intellectual Capital on Firms' Market Value and Financial Performance. Journal of Intellectual Capital, 12(1), 132-151. https://doi.org /10.1108/14691931111097944

Meilani, S. E. R., Andraeny, D., \& Rahmayati, A. (2014). Analisis Kinerja Perbankan Syariah di Indonesia dengan Menggunakan Pendekatan Islamicity Indices. In Seminar Nasional dan The 3rd Call for Syariah Paper (Syariah Paper 
Accounting FEB UMS) (pp. 22-38).

Mutia, E., Jannah, R., \& Rahmawaty. (2016). Islamicity Performance Index of Islamic Bank Indonesia.

Nawaz, T., \& Haniffa, R. M. (2017). Determinants of Financial Performance of Islamic Banks: An Intellectual Capital Perspective. Journal of Islamic Accounting and Business Research, 8(2), 130-142. https://doi.org/10.1108 /JIABR06-2016-0071

Nurhudha, A. S., \& Suwarti, T. (2014). Analisis Pengaruh Corporate Social Responsibility, Intellectual Capital, dan Kinerja Lingkungan terhadap Kinerja Keuangan Perusahaan Manufaktur yang Terdaftar di Bursa Efek Indonesia. In Prosiding Seminar Nasional Multi Disiplin Ilmu \& Call for Papers Unisbank (pp. $1-11)$.

OJK. (2018). Statistik Perbankan Syariah Januari 2018. Retrieved March 17, 2018, from www.ojk.go.id

Ousama, A. A., \& Fatima, A. H. (2015). Intellectual Capital and Financial Performance of Islamic Banks. International Journal of Learning and Intellectual Capital, 12(1), 1-15. https://doi.org/10.1504/IJLIC.2015.067822

Santoso, S. (2012). Pengaruh Modal Intelektual dan Pengungkapannya terhadap Kinerja Perusahaan. Jurnal Akuntansi Dan Keuangan, 14(1), 16-31. https://doi.org/10.18196/JAI-2015.0035

Sekaran, U., \& Bougie, R. (2017). Metode Penelitian untuk Bisnis: Pendekatan PengembanganKeahlian (6th ed.). Jakarta: Salemba Empat.

Sugiyono. (2010). Metode Penelitian Pendidikan Pendekatan Kuantitatif, Kualitatif, dan R\&D. Bandung: Alfabeta.

Ulum, I. (2013). iB-VAIC: Model Pengukuran Kinerja Intellectual Capital Perbankan Syariah di Indonesia. Jurnal Inferensi, 7(1), 183-204.

Wernerfelt, B. (1984). A Resource-Based View of the Firm. Strategic Management Journal, 5(2), 171-180. https://doi.org/10.1002 /smj.4250 050207

Zéghal, D., \& Maaloul, A. (2010). Analysing Value Added as an Indicator of Intellectual Capital and its Consequences on Company Performance. Journal of Intellectual Capital, 11(1), 39-60. https://doi.org/10.1108 /14691931011013325 